\title{
Retraction
}

\section{Retracted: Obesity as a Consequence of Gut Bacteria and Diet Interactions}

\author{
International Scholarly Research Notices
}

Received 9 March 2015; Accepted 9 March 2015

Copyright (C) 2015 International Scholarly Research Notices. This is an open access article distributed under the Creative Commons Attribution License, which permits unrestricted use, distribution, and reproduction in any medium, provided the original work is properly cited.

The paper titled "Obesity as a Consequence of Gut Bacteria and Diet Interactions" [1], published in International Scholarly Research Notices, has been retracted, upon the authors' request, as it is essentially identical in content with a previously published paper by the same authors titled "Bacteria and Obesity: The Proportion Makes the Difference," published in Surgery: Current Research (2013) 3:152.

\section{References}

[1] K. Kotzampassi, E. J. Giamarellos-Bourboulis, and G. Stavrou, "Obesity as a consequence of gut bacteria and diet interactions," ISRN Obesity, vol. 2014, Article ID 651895, 8 pages, 2014. 